\title{
THE EFFECT OF PRE-PHACOEMULSIFICATION EDUCATION ON CATARACT PATIENTS' ANXIETIES IN RUMAH SAKIT ISLAM BANJARMASIN
}

\author{
Rabiyatul Adawiah', Yurida Olviani' ${ }^{2}$, Sukarlan $^{3}$ \\ ${ }^{12}$ Faculty of Nursing \& Health Science, University of Muhammadiyah Banjarmasin, Indonesia \\ ${ }^{3}$ Dr Moch Ansari Saleh Hospital Banjarmasin South Kalimantan, Indonesia \\ e-mail: Rabiatuladawiah01@gamil.com ${ }^{1}$, yuridaolviani@gamil.com ${ }^{2}$,
}

\begin{abstract}
Patients who will experience phacoemulsification often experience anxiety due to the lack of information provided. This information was provided in the education carried out by nurses before the phacoemulsification action. This study aims to determine the effect of pre-phacoemulsification education on anxiety in cataract patients at the Islamic Hospital in Banjarmasin. This study used a preexperimental design using One Group Pretest Posttest Design. The population was all preoperative phacoemulsification patients at the Banjarmasin Islamic Hospital Eye Polyclinic from 21 November to 21 December 2020 with accidental sampling technique totaling 20 people. Data analysis used Wilcoxon signed rank test. The results showed that there was a decrease in anxiety from moderate anxiety to mild anxiety before being given education with a value of $\rho=0.000$. Nurses are expected to conduct prephacoemulsification education for cataract patients using the SOP that has been determined by the hospital.
\end{abstract}

Keywords: Anxiety, Cataract, Education

\begin{abstract}
Abstrak
Pasien yang akan mengalami tindakan Phacoemulsifikasisering mengalami kecemasan karena kurangnya informasi yang diberikan. Pemberian infromasi ini diperoleh dari edukasi yang dilakukan oleh perawat sebelum tindakan phacoemulsifikasidilakukan. Penelitian ini bertujuan untuk mengetahui pengaruh edukasi pre-phacoemulsifikasiterhadap kecemasan pasien katarak di Rumah Sakit Islam Banjarmasin. Penelitian ini menggunakan desain pre-eksperimen dengan menggunakan rancangan one group pretest posttest design. Populasi adalah semua pasien pre-operasi phacoemulsifikasidi Poliklinik Mata pada tanggal 21 November sampai dengan 21 Desember 2020 dengan tekhnik accidental sampling berjumlah 20 orang. Analisis data menggunakan wilcoxon signed rank test. Hasil Penelitian menunjukkan penurunan kecemasan dari kecemasan sedang menjadi kecemasan ringan sebelum ke sesudah diberikan edukasi dengan nilai $\rho=0,000$. Penelitian ini menyarankan agar perawat sebaiknya melakukan edukasi pre-phacoemulsifikasikepada pasien katarak menggunakan SOP yang telah dientukan oleh rumah sakit.
\end{abstract}

Kata Kunci: Edukasi,Katarak, Kecemasan 
Jurnal Keperawatan Suaka Insan (JKSI) Vol. 6, No. 2, Desember 2021

\section{Pendahuluan}

Katarak adalah opasitas lensa kristalina yang normalnya jernih. Biasanya terjadi akibat proses penuaan tapi dapat timbul pada saat kelahiran (katarak kongenital). Dapat juga berhubungan dengan trauma mata tajam maupun tumpul, penggunaan kortikosteroid jangka panjang, penyakit sistemik, pemajanan radiasi, pemajanan yang lama sinar ultraviolet, atau kelainan mata lain seperti uveitis anterior (Smeltzer, 2012).

Angka kejadian katarak di dunia menurut data terakhir dari WHO, katarak menyebabkan 51\% dari kebutaan penduduk dunia, yang mewakili sekitar 20 juta orang tahun 2010. Estimasi jumlah orang dengan gangguan penglihatan di seluruh dunia pada tahun 2010 adalah 285 juta orang, sekitar 45 juta orang menderita kebutaan dan 246 juta orang mengalami low vision. Pada tahun 2018 didapatkan data 180 juta orang di seluruh dunia mengalami gangguan penglihatan, dari angka tersebut terdapat antara 40-45 juta menderita kebutaan dan 1 diantaranya terdapat di South East Asia (World Health Organization, Prevention of Blindness Program, 2018).

Indonesia merupakan negara dengan angka kebutaan tertinggi di Asia Tenggara. Jumlah penderita katarak di Indonesia saat ini berbanding lurus dengan jumlah penduduk usia lanjut. Insiden katarak adalah $0,1 \%$ pertahun atau setiap tahun diantara 1.000 orang terdapat satu orang penderita baru katarak. Penduduk Indonesia juga memiliki kecendrungan menderita katarak 15 tahun lebih cepat dibandingkan dengan penduduk yang berada didaerah subtropik. Berdasarkan Riset kesehatan penglihatan tidak pulih sepenuhnya $(19,6 \%)$, terjadi komplikasi selama operasi (9\%), tindakan operasi (7\%), operasi gagal (7\%), menjadi buta (7\%), tindakan anesthesia (6\%) (Ramirez, 2017).

Angka kebutaan di Kalimantan Selatan tahun 2018 adalah 9.478 kasus dengan 87,7\% disebabkan oleh katarak sebesar 4,2 persen (rentang: 1,4 sampai 7 persen) tertinggi di Hulu Sungai Tengah, sedangkan proporsi kebutaan sebesar 0,6 persen (rentang: 0,2 sampai 0,6 persen) tertinggi di Hulu Sungai Tengah.
Proporsi kebutaan tingkat provinsi sebesar 0,6 persen, lebih rendah dari proporsi tingkat nasional $(0,9$ persen $)$ dan terdapat 4 kabupaten yang menunjukkan proporsi lebih tinggi dibanding proporsi tingkat provinsi (Riskesdas, 2018). Kasus katarak di RS Islam mulai tahun 2019 adalah sebesar 229 pasien dan mengalami tren peningkatan kasus tiap bulannya.

Tindakan penting yang dilakukan untuk penyakit katarak adalah dilakukan tindakan operasi. Salah satu jenis tindakan operasi yang dilakukan adalah tindakan Phecoemulsifikasi. Phacoemulsifikasiadalah salah satu tekhnik pembedahan yang menggunakan vibrator ultrasonik (laser), karena operasi ini tidak membutuhkan banyak jahitan di bagian kornea atau sklera anterior (Bruce, 2015).

Operasi merupakan salah satu sumber kecemasan pasien. Kecemasan sangat berkaitan dengan tidak pasti dan tidak berdaya, keadaan emosi ini tidak memiliki obyek yang spesifik. Kecemasan berbeda dengan rasa takut, yang merupakan penilaian intelektual terhadap suatu yang berbahaya (Stuart \& Sundeen, 2012). Kecemasan preoperasi katarak sering kali mempengaruhi sebagian besar pasien. Penelitian yang dilakukan untuk menilai tingkat kecemasan pada pasien katarak mendapatkan hasil sebanyak 55,6\% responden merasa cemas sebelum melakukan operasi dengan alasan yang berbeda-beda yaitu, cemas karena khawatir penglihatan tidak pulih sepenuhnya $(19,6 \%)$, terjadi komplikasi selama operasi (9\%), tindakan operasi $(7 \%)$, operasi gagal $(7 \%)$, menjadi buta $(7 \%)$, tindakan anesthesia $(6 \%)$ (Ramirez, 2017).

Penelitian Anggraeni (2018) menemukan bahwa tingkat kecemasan pada klien pre operasi katarak di Rumah Sakit Mata SMEC Balikpapan didapatkan tingkat kecemasan berat sebanyak 3 orang (2.9\%), kecemasan sedang sebanyak 17 orang (16.5\%), kecemasan ringan sebanyak 38 orang (36.9\%), tidak ada kecemasan sebanyak 45 orang $(43.7 \%)$ dan tidak ditemukan kecemasan berat sekali/panik. Hal ini didukung oleh penelitian Cholifah (2018) yang menyatakan bahwa tingkat kecemasan pasien paling banyak adalah kategori ringan sebanyak 58 responden $(72.5 \%)$, kecemasan sedang sebanyak 17 
Jurnal Keperawatan Suaka Insan (JKSI) Vol. 6, No. 2, Desember 2021

responden $(21.3 \%)$ dan kecemasan berat sebanyak 5 responden $(6.2 \%)$.

Ketakutan dan kecemasan yang dialami pasien dapat mempengaruhi respon fisiologis tubuh yang ditandai dengan adanya perubahanperubahan fisik seperti meningkatkan frekuensi nadi tekanan darah naik dan peningkatan frekuensi pernafasan, serta gerakan-gerakan tangan yang tidak terkontrol, telapak tangan yang lembab, gelisah, menanyakan pertanyaan yang sama berulangkali, sulit tidur sering berkemih, sakit kepala, dan penglihatan kabur. Persiapan yang baik selama periode operasi membantu menurunkan risiko operasi dan meningkatkan pemulihan pasca bedah (Long dalam Sari, 2016). Tindakan edukasi pre operasi merupakan salah satu tindakan yang dapat mengurangi kecemasan pasien pre operasi. Edukasi sebagai suatu proses dimana informasi diberikan dari satu orang ke orang lain secara langsung dalam pertemuan tatap muka, memberikan konseling, melakukan pencatatan, dan melaporkan pengkajian berkelanjutan. Edukasi pre operatif membantu pasien untuk memahami dan meyiapkan mental untuk melakukan prosedur pembedahan serta penyembuhan post operatif (McEwen \& Wills, 2011).

Hasil studi pendahuluan yang dilakukan peneliti di RS Islam Banjarmasin belum melaksanakan edukasi pre-operasi phecoemulsifikasi, pemberian informasi tentang operasi hanya diberikan pada saat melakukan informed consent dan tidak berdasarkan pedoman edukasi karena tidak memiliki pedoman edukasi. SOP tentang pemberian edukasi pre operasi phacoemulsifikasi juga belum ada di RS Islam Banjarmasin.

Wawancara juga dilakukan peneliti kepada pasien yang akan dilakukan tindakan phacoemulsifikasi, dari 10 orang yang diwawancara 8 orang menyatakan hanya dijelaskan tentang bagaimana tindakan phacoemulsifikasi dan biaya yang harus ditanggung pasien, sedangkan 2 orang lainnya tidak ada diberikan penjelasan, hanya dijelaskan tentang biaya. Peneliti juga mewawancaraai pasien yang telah selesai menjalani operasi phacoemulsifikasi, dari 10 orang yang diwawancarai, 7 orang menyatakan cemas dan selalu menanyakan tentang kondisinya, cara perawatan luka operasi dan kesembuhan penyakitnya, sedangkan 3 orang menyatakan menerima apapun kondisi yang dialaminya.

Berdasarkan fenomena diatas, tergambar bahwa para pasien yang menjalani operasi khususnya operasi phacoemulsifikasi menunjukan tanda-tanda kecemasan sehingga perlu dilakukan upaya-upaya tindakan keperawatan yang dapat mengurangi kecemasan tersebut yaitu salah satunya pemberian edukasi pre-operasi, untuk itu peneliti tertarik untuk meneliti lebih lanjut tentang "Pengaruh Edukasi Pre Phacoemulsifikasi terhadap Kecemasan Pasien Katarak di Rumah Sakit Islam Banjarmasin.”

\section{Metode Penelitian}

Jenis penelitian yang digunakan dalam penelitian ini adalah Pre Eksperimen dengan menggunakan rancangan One Group Pretest Posttest Design. Populasi dalam penelitian ini yaitu semua pasien pre operasi phacoemulsifikasi di Poliklinik Mata RS Islam Banjarmasin pada tanggal 21 November - 21 Desember 2020 yang diambil dengan teknik accidental sampling berjumlah 20 orang. Penelitian dilakukan di Poliklinik Mata RS Islam Banjarmasin pada 21 November sampai dengan 21 Desember 2020. Teknik pengumpulan data yang digunakan peneliti yaitu menggunakan State and Trait Anxiety Inventory dari Spielberg. Analisa data yang digunakan peneliti ini adalah uji wilcoxon signed rank test. 
Jurnal Keperawatan Suaka Insan (JKSI) Vol. 6, No. 2, Desember 2021

\section{Hasil Penelitian}

Hasil penelitian ini dapat ditunjukkan dalam tabel-tabel sebagai berikut:

\section{Tabel 1. Distribusi Frekuensi Karakteristik Responden berdasarkan usia di RS Islam Banjarmasin}

\begin{tabular}{|c|c|c|c|}
\hline \multirow[t]{2}{*}{ No } & \multirow[t]{2}{*}{ Karakteristik } & \multicolumn{2}{|c|}{ Jumlah } \\
\hline & & $\mathbf{n}$ & $\%$ \\
\hline \multirow[t]{5}{*}{1} & Usia & & \\
\hline & 45-59 tahun & 11 & 55 \\
\hline & $60-74$ tahun & 7 & 35 \\
\hline & $75-90$ tahun & 2 & 10 \\
\hline & Jumlah & 20 & 100 \\
\hline \multirow[t]{7}{*}{2} & Tingkat Pendidil & an & \\
\hline & $\begin{array}{l}\text { Tidak sekolah / } \\
\text { tidak tamat } \\
\text { sekolah }\end{array}$ & 1 & 5 \\
\hline & SD sederajat & 3 & 15 \\
\hline & SMP sederajat & 6 & 30 \\
\hline & SMA sederajat & 10 & 50 \\
\hline & $\begin{array}{l}\text { Perguruan } \\
\text { Tinggi }\end{array}$ & 0 & 0 \\
\hline & Jumlah & 20 & 100 \\
\hline \multirow[t]{4}{*}{3} & Jenis Kelamin & & \\
\hline & Laki-laki & 9 & 45 \\
\hline & Perempuan & 11 & 55 \\
\hline & Jumlah & 20 & 100 \\
\hline \multirow[t]{7}{*}{4} & Status Pekerjaan & & \\
\hline & $\begin{array}{l}\text { PNS / TNI / } \\
\text { Polisi }\end{array}$ & 0 & 0 \\
\hline & $\begin{array}{l}\text { Tidak bekerja / } \\
\text { Pensiunan }\end{array}$ & 14 & 70 \\
\hline & Buruh & 4 & 20 \\
\hline & Pedagang & 1 & 5 \\
\hline & Pegawai swasta & 1 & 5 \\
\hline & Jumlah & 20 & 100 \\
\hline
\end{tabular}

Tabel 1. menunjukan bahwa karakteristik responden berdasarkan usia di RS Islam Banjarmasin didapatkan bahwa terbanyak responden adalah berusia 45-59 tahun yaitu sebesar 55\%. Karakteristik responden berdasarkan pendidikan terbanyak adalah SMA sederajat yaitu sebanyak 10 responden atau 50\%. Karakteristik responden berdasarkan jenis kelamin terbanyak adalah perempuan yaitu sebanyak 11 responden atau 55\% dari total responden. Sebagian responden adalah tidak bekerja/ pensiunan yaitu sebanyak 14 orang atau $70 \%$.
Tabel 2. Kecemasan pasien katarak sebelum dilakukan edukasi prePhacoemulsifikasi di Rumah Sakit Islam Banjarmasin.

\begin{tabular}{clcc}
\hline \multirow{2}{*}{ No. } & \multirow{2}{*}{ Kecemasan } & \multicolumn{2}{c}{ Jumlah } \\
& & n & \% \\
\hline 1 & Tidak/Cemas Ringan & 1 & 5 \\
2 & Cemas Sedang & 16 & 80 \\
3 & Cemas Berat & 3 & 15 \\
\hline & Jumlah & 20 & 100 \\
\hline
\end{tabular}

Tabel 2 menunjukkan bahwa sebagian besar kecemasan pasien katarak sebelum dilakukan edukasi pre-phacoemulsifikasi di Rumah Sakit Islam Banjarmasin terbanyak adalah kecemasan sedang yaitu sebesar $80 \%$.

Tabel 3. Kecemasan pasien katarak sesudah dilakukan edukasi pre Phacoemulsifikasidi Rumah Sakit Islam Banjarmasin.

\begin{tabular}{clcc}
\hline \multirow{2}{*}{ No. } & \multirow{2}{*}{ Kecemasan } & \multicolumn{2}{c}{ Jumlah } \\
& & f & \% \\
\hline 1 & Tidak/Cemas Ringan & 16 & 80 \\
2 & Cemas Sedang & 4 & 20 \\
3 & Cemas Berat & 0 & 0 \\
\hline \multicolumn{2}{l}{ Jumlah } & 20 & 100 \\
\hline
\end{tabular}

Sebagian besar kecemasan pasien katarak sesudah dilakukan edukasi prephacoemulsifikasi di Rumah Sakit Islam Banjarmasin adalah kecemasan ringan yaitu sebesar 16 orang atau $80 \%$.

Tabel 4. Pengaruh edukasi prephacoemulsifikasi terhadap kecemasan pasien katarak di Rumah Sakit Islam Banjarmasin.

\begin{tabular}{llccl}
\hline No & Kecemasan & \multicolumn{2}{c}{$\begin{array}{c}\text { Pre Edukasi } \\
\text { Phecoemulsifikasi } \\
\text { Sebelum }\end{array}$} & Pesudah \\
& & 1 & 16 & \\
\hline 1 & Ringan & 16 & 4 & \multirow{2}{*}{0,000} \\
2 & Sedang & 3 & 0 & \\
3 & Berat & 20 & 20 & \\
\hline
\end{tabular}

Hasil analisis pada tabel 4 menunjukkan bahwa dengan uji wicoxon signed rank test didapatkan bahwa $\rho=0,001$, hal ini berarti bahwa Ho ditolak sehingga Ha diterima dengan kata lain ada pengaruh edukasi pre Phacoemulsifikasiterhadap kecemasan pasien katarak di Rumah Sakit Islam Banjarmasin. 
Jurnal Keperawatan Suaka Insan (JKSI) Vol. 6, No. 2, Desember 2021

\section{Pembahasan}

a. Kecemasan pasien katarak sebelum dilakukan edukasi pre phacoemulsifikasi di Rumah Sakit Islam Banjarmasin

Hasil penelitian kecemasan pasien katarak sebelum dilakukan edukasi pre Phacoemulsifikasi terbanyak adalah kecemasan sedang yaitu sebesar 80\%. Hal ini tergambar dari responden yang mengeluhkan perasaan kurang tenang, tegang, agak tertekan, merasa kesal, khawatir, agak takut, gugup, gelisah, bimbang dan bingung dalam menghadapi penyakit dan tindakan phacoemulsifikasi yang akan dijalani responden.

Evans (2013) menyatakan bahwa kecemasan sebelum operasi bisa terjadi dan ini juga akan berhubungan dengan tingginya kecemasan setelah operasi. Hawari (2015) berpendapat bahwa ancaman terhadap integritas fisik, penurunan dalam melakukan kegiatan sehari-sehari dikarenakan adanya ketidakmampuan fisiologis, rencana dilakukan operasi merupakan salah satu bentuk ancaman akan integritas fisik sehingga timbul kecemasan pada pasien. Operasi merupakan tindakan pengobatan yang banyak menimbulkan kecemasan, operasi yang ditunggu pelaksanaannya akan menyebabkan kecemasan pada pasien. Kecemasan yang terjadi di hubungkan dengan rasa nyeri, kemungkinan cacat, menjadi bergantung dengan orang lain dan mungkin kematian (Potter dan Perry,2015). Stuart (2012) menunjukkan bahwa faktor predisposisi kecemasan adalah adanya ancaman yang mengganggu integritas diri, salah satu ancaman tersebut adalah prosedur pembedahan.

Penelitian Angreny (2018) menemukan bahwa respon kecemasan seringkali muncul pada pasien yang akan dilakukan tindakan pembedahan. Kecemasan merupakan suatu perasaan emosi yang tidak mempunyai objek yang spesifik dan dialami secara subjektif. Klien yang akan menjalani operasi katarak mengalami kecemasan tertinggi pada saat pre-operatif. Hal ini sejalan dengan temuan penelitian Wahnuningtyas
(2016) yang menunjukkan bahwa tingkat kecemasan klien pre operasi katarak yaitu cemas ringan sebanyak $32 \%$, sedang $40.2 \%$, dan berat sebanyak $27.8 \%$.

Penelitian ini menunjukkan bahwa kecemasan pasien sebelum dilakukan edukasi pre-phacoemulsifikasidi Rumah Sakit Islam Banjarmasin terbanyak adalah kecemasan sedang. Hal ini terjadi karena pasien dan keluarga belum mengetahui tentang penyakit, prognosa, tingkat kesembuhan setelah dilakukan tindakan, prosedur tindakan dan komplikasi serta adminstrasi termasuk biaya yang dikeluarkan. Selain itu bila dilihat dari umur reponden terbanyak adalah 45-59 tahun merupakan masa masih bisa untuk produktif bahkan sebagian masih berstatus sebagai tulang punggung keluarga hal ini merupakan salah satu faktor menambah tingkat kecemasan kepada responden.

Dilihat dari tingkat pendidikan responden terbanyak adalah tingkat SMA. Responden yang mengalami penyakit akan lebih cemas tentang penyakitnya tetapi apabila diberikan informasi yang tepat maka responden cepat menerima dan lebih memahami dengan baik. Dilihat dari status pekerjaan terbanyak adalah tidak bekerja atau pensiunan dimana pada masa ini segala pembiayaan tergantung dari orang lain sehingga kemungkinan kecemasan pasien bertambah karena belum mendapatkan tentang informasi biaya yang diperlukan untuk berobat. Sedangkan, apabila dilihat dari jenis kelamin terbanyak adalah perempuan dimana perempuan memiliki tingkat kecemasan lebih tinggi dari laki-laki.

\section{b. Kecemasan pasien katarak sesudah dilakukan edukasi pre Phacoemulsifikasidi Rumah Sakit Islam Banjarmasi}

Hasil penelitian menunjukkan bahwa kecemasan ringan sesudah dilakukan edukasi pre-phacoemulsifikasidi Rumah Sakit Islam Banjarmasin yaitu sebanyak $80 \%$. Hal ini tergambar dari sudah berkurangnya keluhan-keluhan seperti pasien sudah tidak merasakan ketegangan, 
Jurnal Keperawatan Suaka Insan (JKSI) Vol. 6, No. 2, Desember 2021

pasien sudah menyatakan perasaan aman, pasien menyatakan perasaan lega karena diberikan infrmasi tentang penyakit dan prosedur tindakan, dan pasien merasakan peningkatan kepercayaan diri dan menyatakan siap menjalani operasi phecoemulsifikasi.

Potter dan Perry (2014) menyatakan bahwa untuk mengurangi atau mengatasi kecemasan pasien, perawat dapat menanyakan hal-hal yang terkait dengan persiapan operasi, antara lain, pengalaman operasi sebelumnya, persepsi pasien dan keluarga tentang tujuan/alasan tindakan operasi, pengetahuan pasien dan keluarga tentang persiapan operasi baik fisik maupun penunjang, pengetahuan pasien dan keluarga tentang situasi/kondisi kamar operasi dan petugas kamar operasi, pengetahuan pasien dan keluarga tentang prosedur (pre, intra, post operasi), pengetahuan tentang latihan-latihan yang harus dilakukan sebelum operasi dan harus dijalankan setalah operasi.

Kecemasan pasien turun menjadi kecemasan ringan terjadi karena klien sudah mendapatkan berbagai macam informasi yang diperlukannya informasi tentang penyakit, prognosa penyakit, kemungkinan kesembuhan, intervensi yang diberikan, tingkat keberhasilan intervensi dan administrasi terutama biaya, hal ini akan dapat menurunkan tingkat kecemasan pasien. Apabila dilihat dari faktor umur responden terbanyak adalah berusia 45-59 tahun dimana pada umur ini responden berada pada usia matang dan lebih menerima kondisi penyakit yang dialaminya hal ini dapat membantu menurunkan kecemasan pada responden.

\section{c. Pengaruh edukasi pre Phacoemulsifikasiterhadap kecemasan pasien katarak di Rumah Sakit Islam Banjarmasin}

Terdapat hubungan antara edukasi pre Phacoemulsifikasiterhadap kecemasan pasien katarak di Rumah Sakit Islam Banjarmasin menggunakan uji wilcoxon dengan taraf kemaknaan $\rho=0,000$. Hal ini dapat dilihat dari hasil penelitian bahwa terbanyak responden sebelum dilakukan edukasi pre-phacoemulsifikasimengalami kecemasan tingkat sedang tetapi setelah diberikan edukasi maka kecemasan menurun menjadi kecemasan tingkat ringan. Prouty, Cooper, Thomas, et.al., (2006) dalam Robby (2015) menyatakan bahwa edukasi pre operasi merupakan pemberian informasi dari perawat ke pasien, keluarga pasien meliputi biaya administrasi, tindakan operasi, persiapan sebelum operasi sampai dengan perawatan pasca operasi operasi. Sebagai tambahan, Ping (2012) menunjukkan bahwa fase pre-edukasi ini sangat diperlukan karena dapat mengurangi tingkat kecemasan pasien. Hal ini didukung oleh Potter (2014) yang menyatakan bahwa salah satu tujuan dari edukasi adalah membantu suatu individu, keluarga, dan masyarakat dalam memelihara kesehatan, memahami kondisi kesehatan, dan menurunkan kecemasan pada individu atas kondisi penyakitnya.

Penelitian Anggreny (2018) menemukan bahwa pemberian informasi mempunyai pengaruh yang efektif dalam mengurangi kecemasan pasien pre bedah. Penyuluhan kesehatan yang dilakukan oleh tenaga kesehatan merupakan bentuk kerjasama antara petugas kesehatan dengan penderita dalam setting rumah sakit yang menguntungkan karena penderita merupakann "captive audience" yang baik (mudah termotivasi) dan diharapkan dapat terjadi komunikasi yang mudah dan baik antara petugas kesehatan dan pasien. Tujuan penyuluhan kesehatan adalah untuk menghilangkan ketakutan dan kekhawatiran keluarga dan pasien, menginformasikan kepada keluarga sehingga menambah pengetahuan tentang masalah dan prognosis penderita serta menjawab keraguan.

Penurunan tingkat kecemasan pasien prephacoemulsifikasidi Rumah Sakit Islam Banjarmasin salah satunya disebabkan karena terpenuhinya kebutuhan akan informasi yang diperlukan pasien. Kebutuhan informasi ini terpenuhi dari edukasi pre-phacoemulsifikasiyang dilakukan oleh perawat sebelum dilakukan 
Jurnal Keperawatan Suaka Insan (JKSI) Vol. 6, No. 2, Desember 2021

tindakan pembedahan. Edukasi ini berisi bahan-bahan informasi yang diperlukan oleh pasien dan keluarga seperti penyakit, kondisi kesehatan, prognosa penyakit, tingkat kesembuhan setelah dilakukan tindakan, prosedur tindakan, dan hal-hal yang berkaitan dengan administrasi seperti biaya.

Responden terbanyak berumur 45-59 tahun dan memiliki tingkat pendidikan SMA pada keadaan ini responden memiliki usia matang dan lebih mudah menerima dan memahami informasi kesehatan yang diberikan oleh tenaga kesehatan karena ditunjang dengan tingkat pendidikan menengah. Selain itu responden juga berjenis kelamin terbanyak adalah perempuan. Perempuan lebih telaten dan patuh dalam melaksanakan anjuran kesehatan yang diberikan oleh tenaga kesehatan, hal-hal ini juga membantu menurunkan kecemasan kepada responden. Selain itu, responden yang dijadikan sampel penelitian memiliki jarak waktu pelaksanaan operasi yang berbeda-beda. Jakar waktu pelaksanaan operasi ini bervariasi paling lama 4 hari sebelum operasi atau paling cepat 2 hari sebelum operasi, hal ini kemungkinan menyebabkan tingkat kecemasan sebelum dan sesudah intervensi edukasi juga dapat berbeda-beda hasilnya.

\section{Kesimpulan}

Sebagian besar responden mengalami kecemasan sedang sebelum dilakukan edukasi pre Phacoemulsifikasiyaitu sebesar $80 \%$. Sebagian besar responden mengalami kecemasan ringan setelah dilakukan edukasi pre Phacoemulsifikasiyaitu sebesar $80 \%$. Ada pengaruh edukasi pre Phacoemulsifikasiterhadap kecemasan pasien katarak di Rumah Sakit Islam Banjarmasin menggunakan uji wilcoxon dengan taraf kemaknaan $\rho=0,000$.

Perawat sebaiknya selalu memberikan edukasi pre operasi kepada semua pasien dengan menggunakan SOP, pedoman dan media yang tersedia agar tingkat pemahaman pasien dan keluarga tentang penyakit dan prosedur lebih baik sehingga menurunkan kecemasan pasien. Peneliti lain dapat melanjutkan penelitian ini dengan meneliti teknik lain untuk mengurangi kecemasan pasien seperti konseling atau dukungan keluarga.

\section{Acknowledgement}

Terima kasih kepada Rumah Sakit Islam Banjarmasin dan Universitas Muhammadiyah Banjarmasin yang telah membantu mewujudkan penelitian ini.

\section{Daftar Rujukan}

Anggreny, L.O (2018) Hubungan Sumber Akses Informasi Terhadap Tingkat Kecemasan Pada Klien Pre Operasi Katarak di Rumah Sakit Mata Smec Balikpapan. Jurnal Nerspedia. Volume 2. Nomor 1. Edisi April 2019

Bruce, J (2015). Lecture Notes Oftalmologi. Alih bahasa: dr. Asri Dwi Rachmawati. Jakarta: Erlangga

Evans, D. C (2013). Alleviating Anxiety and Preventing Panic Attacks in the Surgical Patient." AORN Journal Volume 97. Nomor 3. Edisi 2013

Hawari, D (2015). Manajemen Stres Cemas Dan Depresi Hypnosis. Jakarta: Fakultas Kedokteran Universitas Indonesia.

Mansjoer, A. (2014). Kapita Selekta Kedokteran. Edisi 4. Jakarta: Media Aesculapius

McEwen \& Wills, (2011). Dasar Teori Keperawatan. Jakarta: EGC

Ping, G (2012). A Preoperative Education Intervention to Reduce Anxiety and Improve Recovery Among Chinese Cardiac Patients: A Randomised Controlled Trial. Thesis, University of Nottingham

Pirhonen, Silvennoinen, and Sillence, (2014). Patient Education as an Information System, Healthcare Tool and Interaction. Information System Education Journal, Volume 25 Nomor 4. Edisi 2014

Potter \& Perry, (2014). Buku Ajar Fundamental Keperawatan: Konsep, Proses, dan Prektik. Edisi 4. Volume 2. 
Jurnal Keperawatan Suaka Insan (JKSI) Vol. 6, No. 2, Desember 2021

Alih Bahasa: Renata Komalasari, dkk. Jakarta: EGC

Riskesdas (2013). Laporan Riset Kesehatan Dasar. Jakarta: Badan Penelitian dan Pengembangan Kesehatan Kementrian Kesehatan RI.

Riskesdas (2018). Laporan Riset Kesehatan Dasar. Jakarta: Badan Penelitian dan Pengembangan Kesehatan Kementrian Kesehatan RI.

Smeltzer, S. (2012). Keperawatan Medikal Bedah. Jakarta: EGC

Stuart, G, W (2012). Buku Saku Keperawatan Jiwa. Edisi 5. Jakarta: Buku Kedokteran EGC.

Tauqir, (2012) Knowledge of patients' visual experience during cataract surgery: a survey of eye doctors in Karachi, Pakistan. BMC Ophthalmology. Volume 12. Nomor 55. Edisi 2012

Wahyuningtyas, S. P. (2016). "Hubungan Tingkat Pengetahuan Tindakan Phacoemulsifikasi Dengan Kecemasan Pada Pasien Katarak Di Rumah Sakit Mata Solo"e. skripsi thesis, Universitas Muhammadiyah Surakarta

World Health Organization, (2018). Prevention of Blindness Program, Infodatin Pusat Data dan Informasi Kementerian Kesehatan RI, 1-7. Hyperlink "http://www.depkes.go.id/download.p hp?file=download/pusdatin/infodatin/i nfodatin-hipertensi.pdf. Diakses pada tanggal 01 April 2021. 
Jurnal Keperawatan Suaka Insan (JKSI) Vol. 6, No. 2, Desember 2021 